\title{
O Tempora! O Mores! The place of boni mores in dignity discourse.
}

\author{
BROWN, J.
}

2020

This article has been published in a revised form in Cambridge Quarterly of Healthcare Ethics https://doi.org/10.1017/S0963180119000872. This version is free to view and download for private research and study only. Not for re-distribution, re-sale or use in derivative works. (c) copyright holder. 


\section{O Tempora! O Mores! The Place of Boni Mores in Dignity Discourse $^{*}$ \\ Jonathan Brown ${ }^{*}$}

* Short title: 'The Place of Boni Mores in Dignity Discourse'

* Lecturer in Law, Robert Gordon University 


\section{Introduction}

The final sentence of my last contribution to this journal, which was written in response to a 2014 article by Charles Foster, ${ }^{\text {i }}$ expressed a hope that it should 'not be the last word on the potential for the actio iniuriarum to influence medical jurisprudence in mixed and Common law jurisdictions, but rather that it should serve to provoke further discussion' ${ }^{\text {ii }}$ I am therefore heartened to see that Professor Foster has deigned to reply to that piece with a well-considered and erudite article of his own ${ }^{\mathrm{iii}}$ and I am grateful to him for choosing to do so.

Foster's reply is critical of several aspects of my piece, oftentimes for good reason. It may be said that I missed the mark somewhat in invoking the jurisprudence of 'dignity' in respect of his rather more narrow contention that medical ethics and bioethics lack analytical tools of this kind. ${ }^{\text {iv }}$ With that said, as Waldron noted in his lecture on Dignity, Rank, and Rights, ${ }^{\mathrm{v}}$ 'dignity seems at home in law' and, indeed, seems to be a distinctly legal idea co-opted by moral philosophers. ${ }^{\mathrm{vi}}$ In line with Foster's own contention that 'to give an account of rights and respect, one necessarily has to resort to the principles on which those ideas are based... one is likely to get more satisfactory answers if one starts from the parent principle, ${ }^{\mathrm{vii}}$ it is here submitted that - insofar as 'dignity' is employed in any meaningful sense in moral and ethical debate - the principles of this philosophical notion are ultimately derived from the historic operation of that principle within the specific sub-discipline of legal philosophy. In many important respects, legal philosophy differs significantly between the Common and Civilian traditions. As such, if 'dignity' is to be afforded any place of prominence as a moral guide, it follows that the scope of the legal conception of dignity ought to be examined in full. Given the recognised differences between the two major legal families, oxymoronic comparative legal scholarship must be regarded as a necessary part of this process. 
My previous article did not provide any comprehensive consideration of this subject. Within the context of that piece, it was not thought necessary to 'definitively determine the source, nature, relevance and meaning of the broad concept of 'dignity' as it exists in legal or ethical thought'; ${ }^{\text {vii }}$ therein, I sought only to illustrate that dignity could be used - indeed, commonly has been used - as a significant, and practically useful, guiding legal principle in the manner suggested by Foster. Though Foster agrees that the legal answers which I posited in respect of the three scenarios which he and I discussed are 'plainly right', ${ }^{\text {ix }}$ he nevertheless argued that 'the dangers of erecting a system of law without prior agreement about what dignity is are exemplified by the actio iniuriarum... one cannot safely or coherently begin to erect a system of law to enshrine and protect dignity unless and until there is broad agreement on the substantive notion of dignity involved'. ${ }^{\mathrm{x}}$

In response, it is here submitted that there presently exists, at the core of the actio iniuriarum, an agreed (amongst judges and jurists, at least) conceptualisation of the nature, relevance and meaning of 'dignity'. Such was not discussed in my original article, but, on the basis of Foster's articulated response, it is accepted that it ought to have been. The actio iniuriarum notion of 'dignity’ is, however, unlikely to be regarded as philosophically sound by all commentators, and many of the problems with the actio iniuriarum identified by Foster can be said to apply in respect of this conception. Notwithstanding the fact that the law has at times 'protected dignity interests adequately - whether or not it has invoked dignity expressly in doing so', ${ }^{\mathrm{xi}}$ however, there remains clear cause for a legal mechanism to expressly protect this interest and that the existence of such a mechanism clearly repudiates any claim that dignity is either useless or vacuous. While such a mechanism could indeed be introduced by primary legislation inspired by the European Convention on Human Rights (ECHR), it is thought that such cannot be regarded as a solid foundation on which to build lasting and robust apparatus of this kind. For that reason, I continue to maintain that, in Scotland, there exists a need for the 
legal profession to re-connect with the actio iniuriarum and in the Common law world there is reason for lawyers, ethicists and moral philosophers to, at the very least, consider the tenets of this action in any discourse concerning 'dignity’.

\section{The Substance of 'Dignity' in the Actio Iniuriarum}

The Romanistic actio iniuriarum can be said to protect 'dignity' in two distinct iterations. At an 'operational level' - that is, at the level of specific, individual claims - the actio recognises, and affords protection to, the dignitas of those recognised as legal persons (personae). ${ }^{\text {xii }}$ At a higher level - indeed, at the core of the action itself - the actio iniuriarum also served to safeguard the existimatio of those persons. ${ }^{\text {xiii }}$ Like the terms 'dignity' and dignitas, existimatio was a complex and multifaceted term. The Roman jurist Callistratus compounded this definitional difficulty, deigning to define the term as denoting a 'position of unimpaired dignitas, which is established by law and custom'. xiv Though it clearly raises issues of its own, given its reliance on the nebulous notion of 'dignitas', Callistratus' definition proved influential in the later ius commune $e^{\mathrm{xv}}$ and was used to construct the first operative doctrine of personality rights which could be claimed 'regardless of one's position or role in society'. ${ }^{\mathrm{xi}}$

The term existimatio was not discussed in my previous article, due to its focus on the practical application, rather than juridical nature, of the actio iniuriarum, but it is here thought that a consideration of the concept, alongside a deeper consideration of dignitas, can be used to provide a clearer picture of the scope and nature of 'dignity' as it subsists within the context of the modern action in Scots and South African law. This, it is submitted, may serve to alleviate Foster's concern that broad consensus as to the substantive notion of 'dignity' is necessary to safely utilise the concept in law. More than this, it is submitted herein that existimatio, within the context of the actio iniuriarum, illustrates the fact that the notion of 
‘dignity’ within iniuria accords, if not completely, at least to a significant extent, with Foster’s contention that 'dignity' 'is objective human thriving'. xvii

The historical discussion contained below serves to illustrate why, in a sense, all occasions of iniuria - even those effected against the corpus or fama of the wronged party might be said to be infringements of 'dignity' if expressed in the English language. Egregious affronts to one's bodily integrity, or reputation, or privacy each affront one's existimatio, since each of these affronts subject one to contumely or disrespect to which one ought not to be subject in civil society. The emphasis on 'respect' within the context of the actio iniuriarum does, of course, recall Macklin’s dismissive critique of 'dignity’. The idea that 'dignity’ can be boiled down to no more than 'respect for persons or for their autonomy' is, however, axiomatically false (whether in the context of the actio iniuriarum or in general). Such is made clear by Macklin's own words. By contending that 'dignity' is no more than 'respect for persons or for their autonomy', xviii Macklin implicitly recognises that the word 'dignity' captures more than either 'respect for persons' or 'personal autonomy' manage to do when working alone.

Respecting a person does not necessarily mean respecting their autonomy ${ }^{\mathrm{xix}}$ and it is obvious that one may respect a person who has no autonomy (either in the sense of 'liberty' to act in accordance with that person's own desires, or the capacity to formulate desires or intentions in the first place). ${ }^{\mathrm{xx}}$ The concept of 'dignity' within iniuria - in the modern sense of dignitas and in all conceptualisations of existimatio - does just that; it allows lawyers, judges and jurists to balance respect for the person's autonomously formed wishes with respect for the person as an entity with legal personality. The person's dignity is intimately connected to their status as a person (that is, the individual could not lay claim to dignity if they were not recognised as a 'person'), but it remains distinct from their personhood. Thus, the actio 
iniuriarum is ultimately about preserving 'dignity' as a legal interest, rather than simply ensuring respect for persons, or respect for the autonomy of those persons.

Dignitas was regarded by the Romans, the jurists of the ius commune and modern Scots and South Africa lawyers as a broad and versatile interest which essentially extends to cover any non-patrimonial 'personality right' ${ }^{\text {xxi }}$ not connected to or vested in one's body or reputation. ${ }^{x i i}$ Although dignitas might now be understood as specifically 'human dignity', such would appear to be inaccurate within the context of Roman law itself, particularly given that slaves - though human beings - were deemed to have no dignitas. ${ }^{\text {xxiii }}$ Dignitas was intimately connected with social standing; the term was fundamentally exclusive, rather than inclusive. Those who were considered personae were afforded at least some measure of recognised dignitas, while those who were excluded from this category were not. Slaves had no standing in society - they were not personae - and so their social standing could not be lowered by their subjection to iniuriae. ${ }^{\text {xiv }}$ Even among personae, dignitas was asymmetrical. The dignitas of all personas was afforded protection by means of the actio iniuriarum, 'but one's degree of dignity, and consequently the level of protection which one enjoyed, differed with societal status. ${ }^{\text {xxv }}$ It was not until the fifteenth century that the word dignitas, or even the term dignitas hominis, came to be associated with what we might today recognise as 'human dignity’. xxvi

That is not to say that the Romans did not recognise an analogue to the modern philosophical notion of 'human dignity'. Cicero, for instance, ostensibly recognised dignitas as a feature of all humankind in his De Officiis, tying the 'dignity of man' to the 'persona of reason' which separates human beings from other animals. ${ }^{x x v i i}$ With that said, however, Cicero's conception cannot be regarded as the progenitor of the modern understanding of ‘dignity’ within the actio iniuriarum. Though a lawyer, Cicero was not a jurist and nor was he, here, seeking to expound a technical or legal definition of dignitas. Indeed, the notion of 
dignitas which he described was not an 'interest' worthy of protection at all, but rather an obligation, to which human beings were subject by dint of their ability to reason, to live in accordance with austere (stoic) Roman principles. In Foster's words, Cicero's interpretation of dignitas thus set the stage for the emergence of 'an understanding of dignity that rendered it almost useless in any medical or bioethical context'. ${ }^{x x v i i i}$

Existimatio then, rather than dignitas, ought to be regarded as the starting point in any consideration of the legal notion of 'human dignity' within the actio iniuriarum. This is so in spite of the fact that the word existimatio is typically (though not exclusively) used in a 'nontechnical' sense in the Roman sources. ${ }^{\text {xxix }}$ Indeed, it is because of its proliferation in non-legal discourse that human non-persons were deemed to enjoy at least some measure of existimatio, in spite of the fact that they were ordinarily barred from claiming dignitas. In effect, the word existimatio was used by the Romans to describe an intrinsic 'human dignity' shared by all human beings in society. This conceptualisation of 'human dignity' was, like dignitas, asymmetrical and it was fundamentally tied to one's social role or civic purpose. It was, however, distinct from one’s social standing. A slave had no social standing to defend, but they obviously had to fulfil a certain civic purpose. Existimatio was, thus, possessed by all and could only be legitimately violated by state-mandated punishment following forensic process. ${ }^{\mathrm{xxx}}$

As noted by Giltaij, 'iniuria as a delict sanctioning transgressions against someone else's existimatio could be traced back as far as Labeo or even earlier in the late Republic'. ${ }^{\mathrm{xxi}}$ Though slaves possessed some measure of existimatio, it remained the case that they had no recourse to remedy in the event of its infringement. With that said, although no slave could raise an actio iniuriarum, a slave's owner (their dominus) would be deemed to be injured if another contumeliously affronted that slave, the owner being taken to have suffered an indignity as a result. ${ }^{\mathrm{xxii}}$ This instance of iniuria against the dominus would be aggravated if the slave held an important job. ${ }^{\text {xxxii }}$ Since, however, the slave alone had no dignitas, it is 
difficult to conceptualise the aggravation as being contingent on the greater social standing bestowed on the slave by dint of their office. Rather, it must be concluded that iniuria inflicted on an important slave was aggravated as a result of the increased level of existimatio possessed by that slave; their social role, if not standing, was recognised as important and therefore they were recognised as possessing a greater measure of 'human dignity' (or, at least, a progenitor of our modern understanding of that term).

As a concept intimately connected with one's good name in society - as one who fails to discharge their societal role is bound to lower their own existimatio - most commentators have typically conceptualised existimatio as reputational in nature: more 'civil honour' than 'human dignity' ${ }^{\text {xxxiv }}$ Such is unsurprising; the notion that slaves might have human dignity by dint of their status as slaves appears anathema to later conceptualisations of 'dignity’ drawn from dignitas; indeed, even the Romans recognised that slavery was contrary to the ius naturale and an invention of the ius gentium. ${ }^{\mathrm{xxxv}}$ Further to this, it is, of course, 'hard to think of an idea more repellent to modern lawyers... than that of human beings having different degrees of worth in the eyes of the law and of society in general'. xxxvi As Descheemaeker and Scott note, however, though this 'asymmetric' notion of dignitas and existimatio is historically bound up with the actio iniuriarum, the delict of iniuria is capable of being conceived of as 'an attack on dignity considered in and by itself... held in the same measure by all'. xxxvii

Both dignitas and existimatio have retained their fundamentally social character within the context of the modern actio iniuriarum. They have, however, been 'levelled-up' in the sense described by Whitman; that is to say that while unimpeachable existimatio and dignitas were once consequences of high status, they have since come to be conceived of as features accorded equally to, and shared by, all in society. ${ }^{\text {xxxiii }}$ The concept of existimatio proved more influential than that of dignitas in the 'levelling-up' process which 'human dignity' underwent in the ius commune literature pertaining to the actio iniuriarum. In constructing a modern 
subjective right to dignity within the actio iniuriarum, the $16^{\text {th }}$ century Donellus drew upon Callistratus' conception of existimatio, rather than the more intuitive Ulpianic conception of dignitas. ${ }^{\text {xxxix }}$ Donellus' innovation, according to Waider, marks a break from the earlier asymmetric notion of 'dignity' as a simple matter of social status. ${ }^{\mathrm{xl}}$

Within the context of Donellus' conception of iniuria, therefore, both 'dignity' and 'human dignity' were inclusive terms which represented rights to be respected by others, free from insult and to live in a society which upheld boni mores - 'good morals'. Indeed, the extent to which one might claim a right to respect or to freedom from insult was and is dependent on society's conceptualisation of 'good morals'; this nebulous term fundamentally subsists at the core of both the inclusive and the exclusive interpretations of 'dignity' and 'human dignity' within the context of the actio iniuriarum.

\section{Boni Mores and the Actio Iniuriarum}

In his response to my article, Foster posed a fair question which was not clearly answered in my first piece: 'who is to say that a defendant's action has compromised or threatened my dignitas?' In suggesting some answers to this question, Foster posits that the conception of dignity present in an open-ended actio iniuriarum might lead to a free-for-all in which untold masses of individuals might raise actions founded on disrespect to the eventual detriment of (as but one example) free speech. ${ }^{\text {xli }}$ This would, indeed, be the case if infringements of dignity, or occasions of disrespect, were determined wholly subjectively, by the affronted party alone. This is not, however, how infringements of dignity are determined within the context of the actio iniuriarum.

The measure of 'infringements' of dignity is, as I noted in my previous piece, partly subjective and partly objective. ${ }^{\text {xlii }}$ The subjective aspect of iniuria is can be determined by the claimant's timeous raising of the action, without them having previously personally barred 
themselves from doing so by, say, forgiving the wrongdoer for their transgression. The fact that the claimant has been so incensed as to resort to litigation in the event of a perceived affront is not sufficient for them to achieve legal remedy for the slight by means of an actio iniuriarum; they must also establish that there objectively exists a reason for them to have been affronted by this conduct. Thus, in order to succeed in their legal action, they must show that the conduct of the wrongdoer was contumelious and contra bonos mores (i.e., 'contrary to good morals’). xliii

Contumelia has been defined in a variety of ways, but Ibbetson has convincingly established that the most appropriate translation of this Latin term would be 'hubris' - i.e., one who behaves contumeliously behaves hubristically, displaying wanton disrespect towards the status of their victim. Sufficiently gross hubris will be regarded as contra bonos mores and so self-evidently satisfy the requirements of iniuria, but certain sources suggest that the requirement that the conduct be contra bonos mores is a separate requirement running parallel to the requirement of contumelia. ${ }^{\text {xliv }}$ The answer is, ultimately, moot, however, as the extent to which the wrongdoer's conduct can be described as contumelious is largely dependent on judicial interpretation of boni mores.

As emphasised by Strauss, the measure of boni mores is not to be understood as 'the customs or society or a particular social group, or of all ethical rules prevailing in society', but rather as 'the juristic notions ('regsopvattinge') of society'. xlv These notions are not, generally, expressed in exact rules and so Strauss concedes that the standard is 'admittedly vague', however it is also noted that such is not necessarily problematic, since the standard is largely analogous to that of 'public policy'. 'Public policy' justifications are routinely employed in Common law jurisdictions and it is clear that 'there is a great deal of unanimity in Western communities' as to the type of conduct which can be said to run contrary to such. ${ }^{\text {xlvi }}$ On Strauss' conception, therefore, conduct which contumeliously harms an individual's legally 
protected interests in a manner which runs contrary to 'public policy' might be described as an attack on that individual's 'dignity'.

It is here submitted that it is for this reason that Foster is correct in saying that 'the law often protects dignity interests adequately without a sophisticated dignity analysis'; ${ }^{\text {lvii }}$ the tools to allow it to do so are common to Common, Civilian and mixed jurisprudence, even if such is not expressly articulated. So, too, is Foster correct in noting that the actio iniuriarum represents 'the rule' (that the law does, or ought to, seek to safeguard 'dignity'); my submission was, and is, simply that as the actio iniuriarum represents a clear case in which the law has not shied away from the language of 'dignity'. Following this, as there exists scholarship linking the concept of 'dignity' within the actio iniuriarum to the well-known and oft-employed standards of 'public policy', any scholarship which seeks to engage with the idea of 'dignity' as a meaningful concept ought to consider occasions in which the notion has been expressly juridically employed.

It is manifestly apparent that 'infringements of dignity are easier to detect than to define'. ${ }^{\text {xviii }}$ One can readily agree that instances of serious assault, or rape, or 'revenge porn' affront the dignity of the victim. ${ }^{\text {xlix }}$ Such is not to say that there is any one universal or universalisable conception of 'dignity', which all persons in all places at all times will regard to have been affronted by the commission of certain specific conduct. That this is not the case is evident from the historical enquiry carried out in the previous section. Rather, this account simply posits that human beings, across space and time, share the ability to recognise occasions in which their societal conception of 'dignity' has been affronted, even if there exists no prior or explicit guidance condemning such novel conduct as wrongful. ${ }^{l}$ If a sufficient number of persons within society regard certain conduct as an affront to dignity, then that conduct will be deemed contra bonos mores and so proscribed by law - either expressly, by dint of written and 
specific rules, or de facto only, by dint of specific judicial pronouncement in light of facts which lead the judges to conclude that a dignity interest has been infringed. ${ }^{\text {li }}$

The legal and societal conception of boni mores is liable to change rapidly; significant shifts in the conceptualisation of conduct which contravenes 'public policy' can occur in a very short space of time. Consider the long-time practice of tabloid newspapers publically 'outing', as homosexual, those with a public profile. Throughout the $20^{\text {th }}$ century, it was regarded as a matter of public interest that the identities of 'closeted' individuals should be made known in the media, particularly while homosexual conduct remained a criminal offence and thereafter due to the dictate of 'section 28' lii By the new millennium, however, public opinion had manifestly turned against the press on this matter, as tabloid readers had come to 'find unwarranted intrusion offensive'. liii Thus, 'outing' a public figure is now seen as a gross invasion of privacy, one to which an appeal to 'freedom of expression' is no answer. This, it is submitted, would make the occurrence of a public 'outing' actionable as iniuria, since the determination of such would ultimately turn on the question of whether or not the defender's actions were contra bonos mores and, at present, 'outing' most certainly is contra bonos mores.

The application, or potential application, of this standard to medical law, medical ethics and bioethics is clear; indeed, in her 2012 piece on the ‘medical exception' - the rule precluding the prosecution of a physician who, acting in good faith, carries out a legitimate medical operation $^{\text {liv }}$ - Lewis emphasised the place of 'public policy' in determining the legitimacy of medical treatment. ${ }^{\text {lv }}$ As discussed above, 'public policy' is analogous to the conception of boni mores within the context of the actio iniuriarum, which consequently informs the notions of 'dignity' and 'human dignity' as they operate within this mechanism. Lewis' contention that new or controversial medical procedures ordinarily come to be accepted not through express legislative or judicial change, but rather incrementally as a result of changing public policy, can be read as the law responding to changing conceptions of the constitution of boni mores. 
A procedure which, at one time, might have been regarded as unlawful or illegitimate may come to be an accepted form of necessary or elective treatment. ${ }^{\text {lvi }}$ On the above analysis, the justification for this may be said to be the fact that while, at one time, social and legal mores regarded such procedures as affronts to the dignity of the patient, or to society in general, such ceased to be the case in line with changing 'public policy'.

The flexibility of the measure of boni mores might therefore, indeed, provide a licence for a degree of judicial discretion and creativity which would make even a Common lawyer who would ordinarily welcome such balk. ${ }^{\text {lvii }}$ To this, it may be replied that the matter is no more problematic than the usual usage of 'public policy' as a metric within law. The actio iniuriarum does not permit judges to become 'unfettered legislators' any more than the 'fair, just and reasonableness' test within the Caparo criteria did so. ${ }^{\text {lviii }}$ While the use of 'public policy’ as a metric has been robustly criticised, it is nevertheless recognised that some cases simply must be decided by reference to matters of policy, and that by their nature such matters of policy cannot be set out in stone in advance of the occurrence of all conduct leading to actions in which the concept might be invoked. Such cases, it is submitted, are those in which recourse to an express and practically useful notion of 'dignity' are required. Indeed, as I indicated in my previous article, the German courts found exactly this to be the case; when the legislature scrapped the actio iniuriarum, the courts were nevertheless forced to construct an analogous allgemeines Persönlichkeitsrecht from references to ‘dignity’ in the Basic Law. This marks a clear example of judicial creativity in an otherwise robustly codified Civilian jurisdiction. ${ }^{\text {lix }}$

Whether or not existimatio, or 'human dignity', has been affronted within the actio iniuriarum is not therefore, as Foster alludes, to be determined by the wronged party alone. Rather, it can be said to turn on the following twofold question: Is the conduct in question sufficiently contumelious to have subjectively harmed the victim and objectively be termed 
contra bonos mores (i.e., has the conduct contravened public policy)? If the first answer is yes, but the second is no, then the complainer will have no access to legal remedy, in spite of the perceived affront to their dignity. If the answer to the first part of the question is no, but the second is answered affirmatively, then the 'victim' will have no recourse to the civil courts, but there may yet be cause for a public action in criminal law. It is only if the answer to both parts of the question is affirmative that the victim might successfully plead an infringement of dignity and so succeed in an actio iniuriarum. In all cases, the court will be able to determine whether or not the defender's conduct contravened 'good morals' by treating such as a public policy decision.

If public policy comes to be that the law should seek to promote, wherever possible, 'human flourishing' in the sense advocated by Foster, then it is submitted that the law would, from this, functionally serve to safeguard 'dignity' in precisely the manner that he describes. This is so on the grounds that the occurrence of iniuria is determined by reference to the standard of boni mores, which is itself identical to the English term 'public policy'. The actio iniuriarum would be counted amongst the primary means of furthering the objective set by Foster, but it certainly would not be the only legal mechanism which could be employed to do so. The point that I made in my initial article consequently stands; in dignity discourse, there is a clear need for oxymoronic comparative law. In the absence of such, a vital conceptual tool which can be used to further the cause of 'dignity', as a practical and useful legal or philosophical concept, may well tragically be lost.

\section{Dignity, Iniuria and Article 8}

The loss of the actio iniuriarum in Scotland would, it is submitted, likewise be tragic. The action was much-maligned in the Roman-Dutch jurisprudence of the $20^{\text {th }}$ century ${ }^{\mathrm{lx}}$ and the delict of iniuria has not been utilised to its full potential within Scots law as a result. ${ }^{\text {lxi }}$ 
Nevertheless, as indicated in my previous article, this mechanism could be used to afford redress to those who have suffered an affront to dignity, howsoever caused. The delict does not rely on a 'pigeonhole system of nominate torts', as does English law; xii nor does it require any 'public' element, as do English crimes such as outraging public decency. A successful actio iniuriarum requires no more than a juridical determination that the human dignity of the pursuer was affronted by the conduct of the wrongdoer.

More significant than this potential as a practical tool for the purposes of this article, however, is the potential for scholars and advocates of 'dignity' to utilise the copious scholarship concerning the actio iniuriarum and the delict of iniuria in constructing a robust legal and philosophical concept of dignity. In Scotland, indeed, there is something of an imperative for jurists and legal practitioners to engage with this material, precisely because Article 8 of the ECHR has been 'brought home' by the Human Rights Act 1998. ${ }^{\text {lxiii }}$ Since the introduction of this legislation, the ECHR rights may be regarded as 'new and fundamental sources of public policy when developing common law areas particularly affected by such considerations,; ${ }^{\text {xiv }}$ tort law and the Scots law of delict are each expressly conceived of as areas so affected. ${ }^{\mathrm{lxv}}$

The ECHR has given those jurisdictions which subscribe to its tenets the means to place dignity at the core of their conception of private law in this 'age of rights'. lxvi To that extent, I agree with Foster - indeed, I truly hope that he is right in saying that 'the Scots law of the actio iniuriarum is likely to evolve well because it must and will evolve with the benefit of the Strasbourg jurisprudence on dignity'. ${ }^{\text {xvii }}$ Within the context of the UK, however, the fragility of the constitutional arrangement in respect of the ECHR is such that it cannot be taken for granted that this instrument will continue to directly apply in domestic jurisprudence in all time coming. Those holding high office have consistently railed against the Human Rights Act 1998 of late and the move to repeal this legislation and replace it with a so-called and nondescript 
'British Bill of Rights' gained pace until the loss of the Conservative Parliamentary majority in 2017. ${ }^{\text {lxvii }}$ Strasbourg jurisprudence pertaining to dignity would, of course, continue to grow even in the absence of the justiciability of the ECHR within the UK's domestic courts, or indeed in the absence of the UK's ascription to the Convention. This would be of little utility to UKbased litigants, who could no longer rely on its tenets for legal protection in domestic law. The imperative for Scotland to develop her common law relating to the actio iniuriarum is therefore apparent. In order to protect individual interests in 'dignity', a private law mechanism to afford redress in the event of infringements of this interest is necessary. Such, as Foster recognises, has the added benefit of being justiciable against private persons, as well as public bodies. ${ }^{\text {.xix }}$

Although I take some issue with his use of the definitive article, I do not disagree in principle with Foster's claim that 'Article 8 of the ECHR is the natural legal vehicle for the idea of human dignity'. ${ }^{\mathrm{xx}}$ For as long as it retains its place in domestic law, Article 8 is a fine vehicle for dignity to employ in travelling to its proper place of prominence in bioethics and jurisprudence. The ECHR is not, however, as Foster contended in his 2014 piece, 'the natural home of dignity'. ${ }^{\text {lxi }}$ Dignity made its home in the actio iniuriarum for some two millennia before Article 8 was more than a glint in the eye of the drafters of the Convention. This implies that the place of dignity within the actio iniuriarum - whether in its ancient or modern contexts - ought to be considered by those who seek to make use of the term as a guiding moral or legal principle.

The lack of consideration paid to the actio iniuriarum in ECHR jurisprudence itself is not surprising, since the actio as described herein and in my previous piece does not now exist in Europe outside of one small jurisdiction, which is generally outshone on the international stage by its larger neighbour. Further to this, though the action has flourished in post-apartheid South Africa, the action has been severely neglected in Scotland. The comparative obscurity of the actio iniuriarum within modern Europe does not detract from its potential utility 
however; as I argued in my last article, within Scotland, it is not too late for the action to be revived in full and in the rest of the United Kingdom there exists cause for the introduction of some comparable concept. If there is need for primary legislation to introduce a means of expressly protecting ‘dignity’ throughout England, Wales and Northern Ireland, however, such should not - as Foster suggests - draw only from 'the dignity principles that are at the core of the ECHR' ${ }^{\text {lxxii }}$ Rather, such legislation should draw on the delict of iniuria in order to give the courts the flexibility to deal with all potential infringements of dignity in their myriad forms.

For that reason, it is submitted that the actio iniuriarum ought to be utilised as a 'light to nations', to use Foster's words, though of course it ought not to be the only light. One cannot now obtain a clear picture of the place of 'dignity' in bioethics or law without engaging with jurisprudence from Strasbourg, or commentary concerning the proliferation of the concept of 'dignity' in the post-Second World War international instruments. But such is precisely my point. In the scholarship of 'dignity', in order to obtain the clearest possible picture of what the term means, if it is to be thought of as more than mere vacuous window-dressing, it behoves scholars to make use of all available resources in constructing their case that 'dignity' is of use as a doctrinal and philosophical tool or principle in legal and ethical debate. The actio iniuriarum is another tool in the lawyer's toolkit and, as 'dignity' might be described as a juristic notion which has been adopted by moral philosophers and ethicists, the notion of 'dignity’ as it subsists within this legal mechanism ought to be considered in setting out any refutation of the claim that the whole concept is utterly vacuous.

\section{Conclusion}

In response to my article, Foster argued five distinct points. I believe that in the course of this article, I have addressed the key concerns raised in that response. It has been established that within the context of the actio iniuriarum there is - broad - agreement as to the substantive 
notion of 'dignity' central to that legal mechanism. This fact means that the actio iniuriarum does not exemplify the dangers of constructing a system of law without prior agreement as to the nature of dignity; indeed, the robust and useful conception of dignity present in the actio iniuriarum is interpreted in line with a legal metric that is well-known even in Common law jurisdictions.

At the core of the legal conception of 'dignity' within iniuria is this concept of boni mores. This notion is both broad and flexible enough to describe 'human flourishing' in the sense articulated by Foster. The term is, in essence, synonymous with that of 'public policy'. For this reason, the introduction of a conception of 'dignity' akin to that contained in the actio iniuriarum could not be taken as a licence for the judiciary to act as unfettered legislators; at least, no more or less so than such a charge can presently be laid at the door of judges who engaging with matters of 'public policy'.

It has long been the case that the law has been able to adequately protect dignity interests without invoking the language of dignity expressly. It is, however, submitted that the Common law's capacity to do so would be better understood if more scholars of dignity were to concern themselves with an examination of dignity within the context of the actio iniuriarum. The link between the notion of boni mores and the contemporary idea of 'public policy' is clear and so it is concluded that Romanistic ideas of dignity are present in the Common law, even if such remain unarticulated. A more detailed oxymoronic comparative legal study of 'dignity’ could shed further light on the true extent and nature of this link.

It is hoped, as Foster posits, that the actio iniuriarum will be the beneficiary of Strasbourg jurisprudence, but it is submitted that the jurisprudence of the ECHR is not, alone, sufficient to properly protect 'dignity' within the context of domestic law in either Scotland or the rest of the United Kingdom. The precariousness of the ECHR (or, rather, the Human Rights 
Act) within the UK is such that in Scotland there is, or ought to be, an impetus to precipitate the place of the actio iniuriarum in this jurisdiction. Even with this practical concern aside, however, there remains a case for - if nothing else - consideration of the place of the actio iniuriarum in dignity scholarship. This is especially the case if there is to be talk of the introduction of primary legislation with a view to protecting dignity interests; in order to craft such legislation, consideration of all legal sources pertinent to this complex, multifaceted and often unpopular philosophical construct is necessary.

${ }^{\mathrm{i}}$ Charles Foster, Dignity and the Ownership and Use of Body Parts, [2014] Cambridge Quarterly of Healthcare Ethics Vol.23, Issue 4, 417

ii Jonathan Brown, Dignity, Body Parts and the Actio Iniuriarum: A Novel Solution to a Common (Law) Problem?, [2018] Cambridge Quarterly of Healthcare Ethics, p.*

iii Charles Foster, Human Dignity: Be Philosophical and European, but not Scottish, [2018] Cambridge Quarterly of Healthcare Ethics

iv Ibid., p.*

${ }^{v}$ Jeremy Waldron, Dignity, Rank, and Rights, The Tanner Lectures on Human Values, Delivered at University of California, Berkeley April 21-23, 2009

vi Ibid., p.209

vii Foster, (n.1), p.420

viii Brown, (n.2), p.*

${ }^{\text {ix }}$ Foster, (n.1), p.418

${ }^{x}$ Foster, (n.3), p.* (Foster's emphasis).

${ }^{x i}$ Foster, (n.3), p.*

xii See Niall Whitty, Overview of Rights of Personality in Scots Law, in Niall R. Whitty and Reinhard Zimmermann, Rights of Personality in Scots Law: A Comparative Perspective, (Dundee: DUP, 2009), p.160

xiii Reinhard Zimmermann, Actio Iniuriarum, in The Law of Obligations: Roman Foundations of the Civilian Tradition, (Oxford: Clarendon Press, 1996), fn.102

xiv Dig.50.13.5.1

${ }^{x v}$ See H. Waider, 'Ars iuris' und 'suum in persona ipsa' bei Hugo Donellus, Ein Beitrag zur Geschichte der Metholodologie und der Lehre von den Menschenrechten, [1961] Archiv für Geschichte der Philosophie 52, p.69

xvi See Jacob Giltaij, Existimatio as "Human Dignity" in Late-Classical Roman Law, [2016] Fundamina 232, p.234

xvii Foster, (n.3), p.*

xviii Ruth Macklin, Dignity is a Useless Concept, [2003] JME 1419, p.1420

xix See Veronica English, Rebecca Mussell, Julian Sheather and Ann Sommerville, Autonomy and its Limits: What Place for Public Good? in Sheila McLean, First Do No Harm: Law, Ethics and Healthcare, (Aldershot: Ashgate, 2006), p.118

xx See John Coggon and José Miola, Autonomy, Liberty and Decision-Making, [2011] Camb. L. J. 523, p.524

xxi Though neither the Romans nor the ius commune jurists conceived of these personality interests as 'rights': See John Blackie, Doctrinal History of the Protection of Personality Rights in Europe in the Ius Commune: General Actions or Specific Actions?, [2009] EJCL 1, p.4 
xxii J. Neethling, J. M Potgieter and P. J Visser, Law of Delict, (4 ${ }^{\text {th }}$ Edition) (Durban: Butterworths, 2001) p.14

xxiii D.47.10.15.35

xxiv Clifford Ando, Paul J du Plessis and Kaius Tuori, The Oxford Handbook of Roman Law and Society, (Oxford: OUP, 2016), p.326

xxv James Gordley, Reconceptualising the Protection of Dignity in Early Modern Europe: Greek Philosophy Meets Roman Law in M Ascheri et al (eds.), Ins Wasser geworfen und Ozeane durchquert, (Böhlau Verlag Köln Weimar, 2003), p.286

xxvi Giltaij, (n.16), p.233

xxvii De Officiis, 1, pp.105-107

xxviii Charles Foster, Human Dignity in Bioethics and Law, (Oxford: Hart Publishing, 2011), p.28

xxix Max Kaser, Infamia und Ignominia in den Römischen Rechtsquellen, [1956] Zeitschrift der Savigny-Stiftung für Rechtsgeschichte: Romanistische Abteilung 220, p.231

${ }^{x x x}$ Giltaij, (n.16), p.246

xxxi Ibid., p.236

xxxii Justinian, Institutes, 4, 4, 3

xxxiii Ibid., 4, 4, 7

xxxiv Abel H. J. Greenidge, Infamia: Its place in Roman Public and Private Law, (Oxford: OUP, 1894), Ch.2

xxxv Dig.1.5.4

xxxvi Eric Descheemaeker and Helen Scott, Iniuria and the Common Law, (Oxford and Portland, Oregon: Hart, 2013), p.21

xxxvii Ibid.

xxxviii James Whitman, Human Dignity in Europe and the United States, in G. Nolte (Ed.), Europe and U.S. Constitutionalism (Strasbourg: Council of Europe Publishing, 2005), p.97

xxxix Donellus, Commentarii de Iure Civili, (1589) 2, 8, 3, pp.229-230

${ }^{\mathrm{xl}}$ Waider, (n.15), p.69

xli Foster, (n.3), p.*

xlii Brown, (n.2), p.*

xliii See David Ibbetson, Iniuria, Roman and English in Eric Descheemaeker and Helen Scott, Iniuria and the Common Law, (Oxford and Portland, Oregon: Hart, 2013), p.43

xliv Ibid., p.43

xlv S. A. Strauss, Bodily Injury and the Defence of Consent, [1964] S. African L. J. 179, p.183

xlvi Ibid., pp.182-183

xlvii Foster, (n.3), p.*

xlviii Brown, (n.2), p.*

xlix See Jonathan Brown, Revenge Porn and the Actio Iniuriarum: Using 'Old Law' to Solve 'New Problems', [2018] Legal Studies 396, passim.

${ }^{1}$ Consider, e.g., Khaliq v HM Advocate 1984 J.C. 23

li This, it is tentatively submitted, may serve, in part, as the rationale for the 'declaratory power of the High Court' - the much-maligned, yet practically extant, express power of the Scottish High Court of Justiciary to declare novel conduct criminal even in there exists no prior proscription of such conduct.

lii I.e., s.28 of the Local Government Act 1988, which prohibited the 'promotion' of homosexuality.

liii See http://news.bbc.co.uk/1/hi/uk/212737.stm

liv See the discussion in Margaret Brazier and Sara Fovargue, Transforming Wrong into Right: What is 'Proper Medical Treatment'?, in Sara Fovargue and Alexandra Mullock, The Legitimacy of Medical Treatment: What Role for the Medical Exception, (London: Routledge, 2016), passim. 


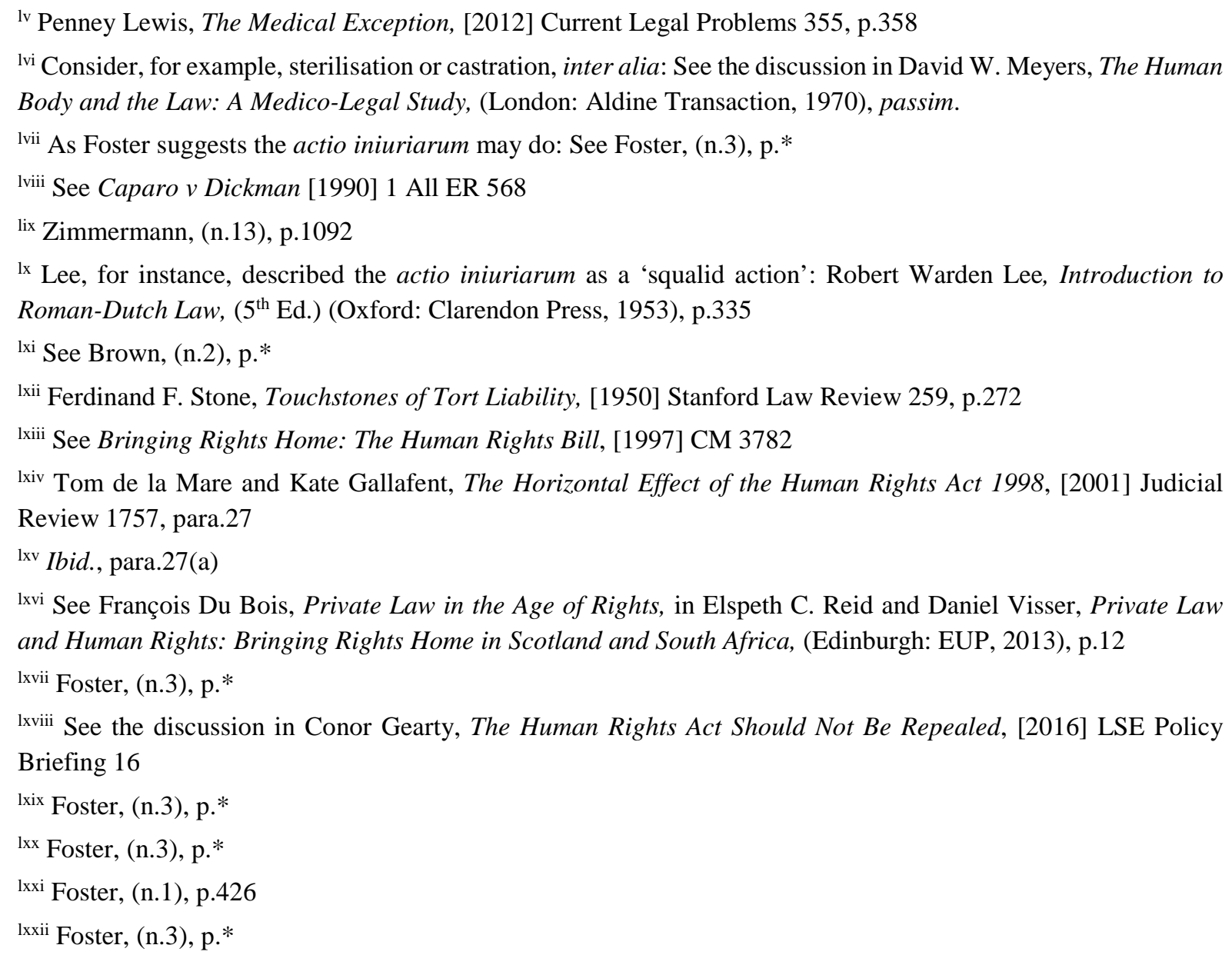

